\title{
THE EFFECT OF THE GEOMETRIC STRUCTURE OF FLOOD PLAIN VEGETATION ON THE PROBABILITY OF PASSING FOR PLANT DEBRIS
}

\author{
Natalia Walczak', Zbigniew Walczak², Mateusz Hämmerling ${ }^{1}$ \\ 1 Department of Hydraulic and Sanitary Engineering, Poznan University of Life Sciences, Piątkowska 94A Str., \\ 60-649 Poznań, Poland, e-mail: natwal@wp.pl, mhammer@up.poznan.pl \\ 2 Institute of Construction and Geoengineering, Poznan University of Life Sciences, Piątkowska 94E Str., 60-649 \\ Poznań, Poland
}

Received: 2016.05 .30

Accepted: 2016.08.08

Published: 2016.09.20

\begin{abstract}
Flood plains are a specific sedimentary environment. They are a natural clarifier and filter for rivers carrying large amounts of heavy metals, biogenic elements and other contaminants transported during high water and floods. Plenty of it is accumulated in the riverbank zone of channels i.e. a buffer strip. This is a relatively narrow strip of land situated along watercourses, often covered with riparian plants. It is functionally associated with river flooding and it forms a transition zone to ecosystems of mixed (oak-lime-hornbeam) forest plants. These plants unquestionably grow into a natural protective system of surface waters against contamination flowing down from areas used for agricultural purposes. Buffer zones provide the opportunity for self-cleaning, and according researchers they are among the most efficient natural tools to protect a catchment area. They can reduce the amount of sediments and nutrients carried by surface water flowing down from agricultural areas. Besides positive effects, the zones are accompanied by the phenomenon of flow blockage, which is particularly hazardous in case of directing great water away from its main channel. Shrubby vegetation retains small elements of plant origin and thus the free flow of water stopped. The article analyses the effect of vegetation structure density on flow conditions for small plant debris on a laboratory scale.
\end{abstract}

Keywords: geometric structure, flood plain, vegetation, debris

\section{INTRODUCTION}

Floods are the most frequent natural hazards. Thus, to reduce a negative impact of flood events is one of the most important tasks in the field of water management. The experience with flood proves that applying only technical flood defences do not provide sufficient protection [Gustowska et al., 2013]. In recent years there have been carried out numerous hydraulic studies relating to water flow through areas covered with trees or shrubs [Dąbkowski, Pachuta 1996, Kubrak and Nachlik, 2003]. There have also been analysed multiple variants regarding the size, type and spacing of trees and shrubs in flood plains and there have been thoroughly specified the rules of hydraulic calculations. Two factors which may have a major impact on the information obtained in the study on the dynamics of this phenomenon particularly draw attention. Firstly, the response of plants to water flow depends on the degree of their elasticity. Secondly, the impact of material lifted by water is conditional on their resistance to motion. As early as in 1996 Dąbkowski and Pachuta [1996] analysed the case of water flow blockage as a result of "rinsing" hay from grasslands.

Trees and shrubs in flood plains are some kind of "a sieve" that captures materials carried by water. This might include mineral bed-load, organic debris (plant debris) and waste (foil). Riverbeds under normal water flow conditions are exposed to transportation of diverse organic material, re- 
ferred to as plant or organic debris. The quality and quantity of debris have a considerable impact on the ecological status of rivers. Considering the conditions of mountain rivers, it primarily includes coarse woody debris, which mainly consists of trees, shrubs and their fragments (trunks, branches, pieces of bark). In contrast, lowland rivers are characterized by fine organic material, which consists of fragments of aquatic and land vegetation growing on flood plains (grass blades, leaves, stems, branches) [Kałuża, Radecki-Pawlik, 2014]. Portions of each vegetation type commonly get into riverbeds following the natural decomposition of dead parts of plants growing on riverbanks and located in watercourses. This phenomenon occurs due to riverside erosion, knockdown by wind or substantial water flows [Radecki-Pawlik et al., 2011]. With gradual clogging of the "sieve", the resistance to water movement increases [Łoś, 2013].

On the basis of on-the-spot visits in river valleys there is no doubt that woodlots and shrub cover found in the inter-embankment are different in altitude, size, age, territory, species, and also in terms of density. The growth is very often composed of annual plants, shrubs and trees of different height.

To evaluate the effect the geometrical structure of vegetation has on flood plains, the study included shrubby and woody vegetation growing separately, and a system covering both vegetation types. A probability evaluation of passing differently shaped plant debris was carried out for vegetation with varying densities at different levels of its immersion.

One of the fundamental hydraulic parameters of river channels is water flow velocity. This parameter is characterized by high variability, which results from the turbulent nature of water movement and from changes during the flow resistance, mainly related to debris movement, vegetation overgrowing the banks and the bottom of river channels, and presence of ice phenomena [Popek et al., 2011].

\section{RESEARCH METHODOLOGY}

A characteristic feature of the analysed area of flood plains is a structure described with the diameter and height (geometric parameters) of vegetation elements. Their distribution (spacing) in the studied zone, that may affect the probability of plant debris blockage, is also of a significant value. The tests were carried out on a physical model made at the water laboratory of Department of Hydraulic and Sanitary Engineering, Poznań University of Life Science. They were conducted in a glass hydraulic channel of rectangular cross section (Fig. 1), $12.0 \mathrm{~m}$ long, $0.46 \mathrm{~m}$ wide and 0.90 $\mathrm{m}$ high, powered by Hydrovar $15 \mathrm{~kW}$. Water was provided to the channel from a tank located below using a short pipeline with a valve (1), which enabled flow control.

The bottom of the physical model (its middle part) had some styrodur attached - material widely used e.g. in construction due to its physical properties (it is harder and less absorbent than Styrofoam). It provided a skeleton used for attaching elements that imitated shrub vegetation as well as trees (Fig. 1).

Plant debris is characterised by different shapes. In the natural environment fine plant debris generally includes spatial elements i.e. portions of bark, branches, dry grass [Hammerling et al., 2013]. On this basis, for laboratory tests there were adopted flat square- (S) and elliptical (E) elements made of styrodur. The decisive parameter was the length of a given element (Table 1).

The measurements were carried out for two variants of predetermined monotonous water flow in the hydraulic channel. The applied methodology is specified by its simple structure and

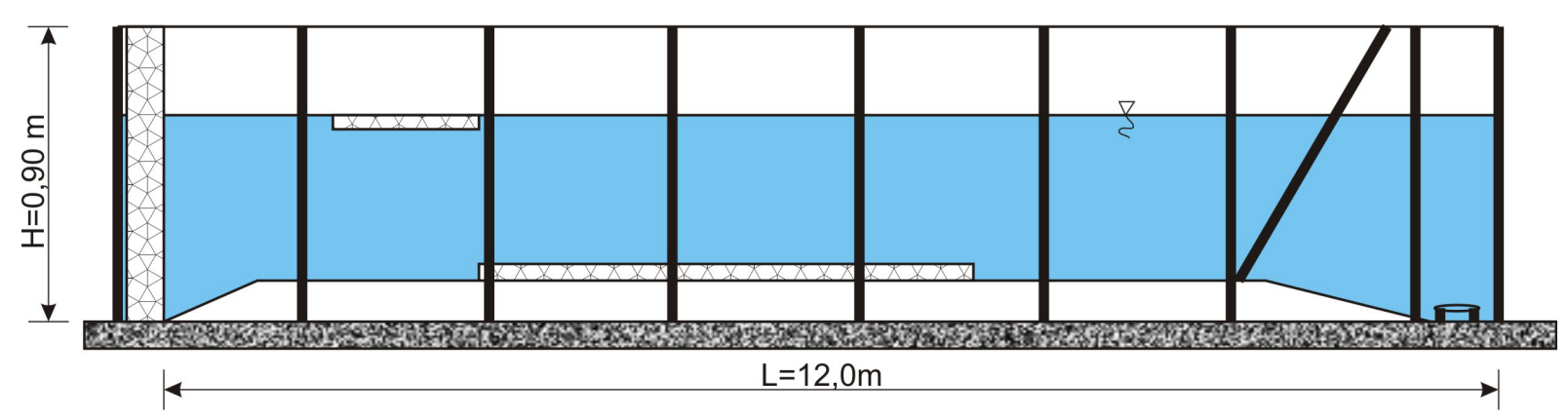

Figure 1. Diagram of the experimental riverbed 
Table 1. Comparison of natural and artificial geometrical parameters of fine plane debris

\begin{tabular}{|c|c|c|c|c|c|c|c|}
\hline \multicolumn{2}{|c|}{ Shape } & \multicolumn{3}{c|}{ Sizes natural debris [m] } & \multicolumn{3}{c|}{ Sizes artificial debris [m] } \\
\cline { 3 - 9 } & & length & width & thickness & length & width & thickness \\
\hline Square & 1K & 0.142 & 0.049 & 0.029 & 0.09 & 0.09 & 0.03 \\
\hline Elliptical & 1E & 0.140 & 0.064 & 0.016 & 0.085 & 0.085 & 0.03 \\
\hline
\end{tabular}

empirical nature, which additionally simplifies calculations [Kubrak et al., 2012]. Based on field research [Walczak and Przedwojski, 2005] there was selected a diameter of cylindrical elements imitating shrubby vegetation, which was $0.003 \mathrm{~m}$, and a diameter of smaller trees equal to $0.022 \mathrm{~m}$. The filling level of the hydraulic channel was adjusted to the height of plant elements, which was for shrubby vegetation $0.33 \mathrm{~m}$, and for trees $0.30 \mathrm{~m}$, respectively. The variants took account of vegetation immersion level, which was smaller for each variant consecutively. The probability evaluation of blocking the imitation of fine plant debris on elements imitating shrubby and woody vegetation was carried out with the assumption that the vegetation density (shrubs and trees) was the number of units per area. In case of shrubby vegetation, the density steadily was decreasing by $25 \%$ (variants 1a-Fig. 3, 1bFig. 4, 1c- Fig. 5). For tests with the use of woody vegetation, the decisive parameter was the shape of spacing. Therefore, there were analysed: the symmetrical spacing (variant $2 a$ ) of elements imitating trees with the shape resembling a rectangle, and the tree spacing (variant $2 b$ ) similar in shape to a triangle. There was also analysed the effect of mixed plant structures on the probability of blocking plant debris assuming the proportion of woody vegetation to shrubby vegetation in the ratio of $1: 2$ (variants $3 a, 3 b$ ).

The probability evaluation of passing the imitation of fine plant debris between cylindrical elements imitating shrubs was carried out with the use of styrodur elements of square-shaped (1K) and ellipse-shaped (1E) plant debris. 20 repetitions were performed for each event.
Table 3 presents the probability of passing for fine plant debris elements $(1 \mathrm{~K}$ and $1 \mathrm{E})$ between cylindrical elements imitating shrubby vegetation having the density of $100 \%, 74 \%$ and $50 \%$ (Variant $1 \mathrm{a}, 1 \mathrm{~b}, 1 \mathrm{c})$. The average plant spacing Xsr was calculated taking into account a horizontal projection of the tested channel bottom area (A1) and the number of plant species $(\mathrm{N})$ per A area.

$$
X s r=\sqrt{\frac{A_{1}}{N}}
$$

In the tested variant with shrubby vegetation, a square-shaped fine plant debris element $(1 \mathrm{~K})$ did not pass at all for the maximum density of vegetation. The next two trials (74 and 50\% density) reached maximally $60 \%$ probability of passing and only with the deepest immersion value. An ellipse-shaped debris element (1E) was characterised by higher probability of passing (even for the least favourable hydraulic conditions).

Analysing Figure 5, it was indicated that the probability of passing for elements imitating fine debris through shrubby vegetation primarily depends on its shape. The highest probability refers to ellipse-shaped debris. Even with low correlation between the average spacing and depth, this type of debris passes with a high probability. In case of square-shaped debris, the highest probability was reached for the density of 29 shrubby vegetation units (minimum) with the immersion level of $0.3 \mathrm{~m}$.

In the next stage of the study it was assumed that there were only trees in the flood plain and for this type of vegetation the experiment was performed using the same as previously de-

Table 2. Variants of distribution of the imitation of shrubby and trees vegetation in the hydraulic channel

\begin{tabular}{|c|c|c|c|c|}
\hline Imitation of vegetation & Area research $\left[\mathrm{m}^{2}\right]$ & Quantity [szt.] & Density [\%] & $\begin{array}{c}\text { Variant of } \\
\text { distribution }\end{array}$ \\
\hline \multirow{3}{*}{ Shrubby vegetation } & \multirow{7}{*}{0.55} & 59 & 100 & variant $1 a$ \\
\hline & & 43 & 74 & variant $1 \mathrm{~b}$ \\
\hline & & 29 & 50 & variant $1 \mathrm{c}$ \\
\hline \multirow{2}{*}{ Trees } & & 8 & 14 & variant $2 a$ \\
\hline & & 7 & 12 & variant $2 b$ \\
\hline \multirow{2}{*}{ Shrubby and trees vegetation } & & 24 & 41 & variant $3 a$ \\
\hline & & 21 & 36 & variant $3 b$ \\
\hline
\end{tabular}



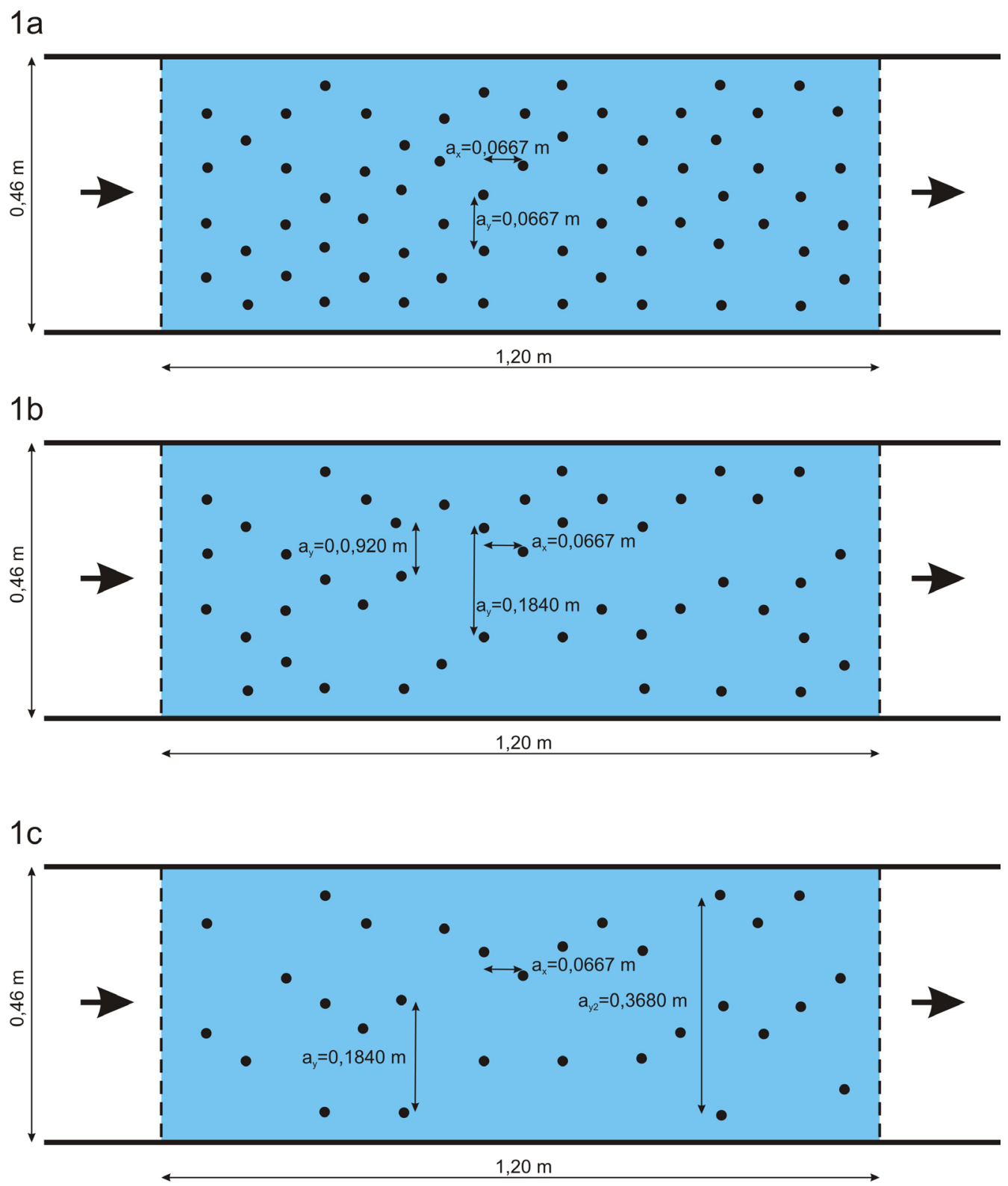

Fig. 2. Diagram of the applied distribution of elements imitating shrubby vegetation in variants $1 \mathrm{a}, 1 \mathrm{~b}, 1 \mathrm{c}$
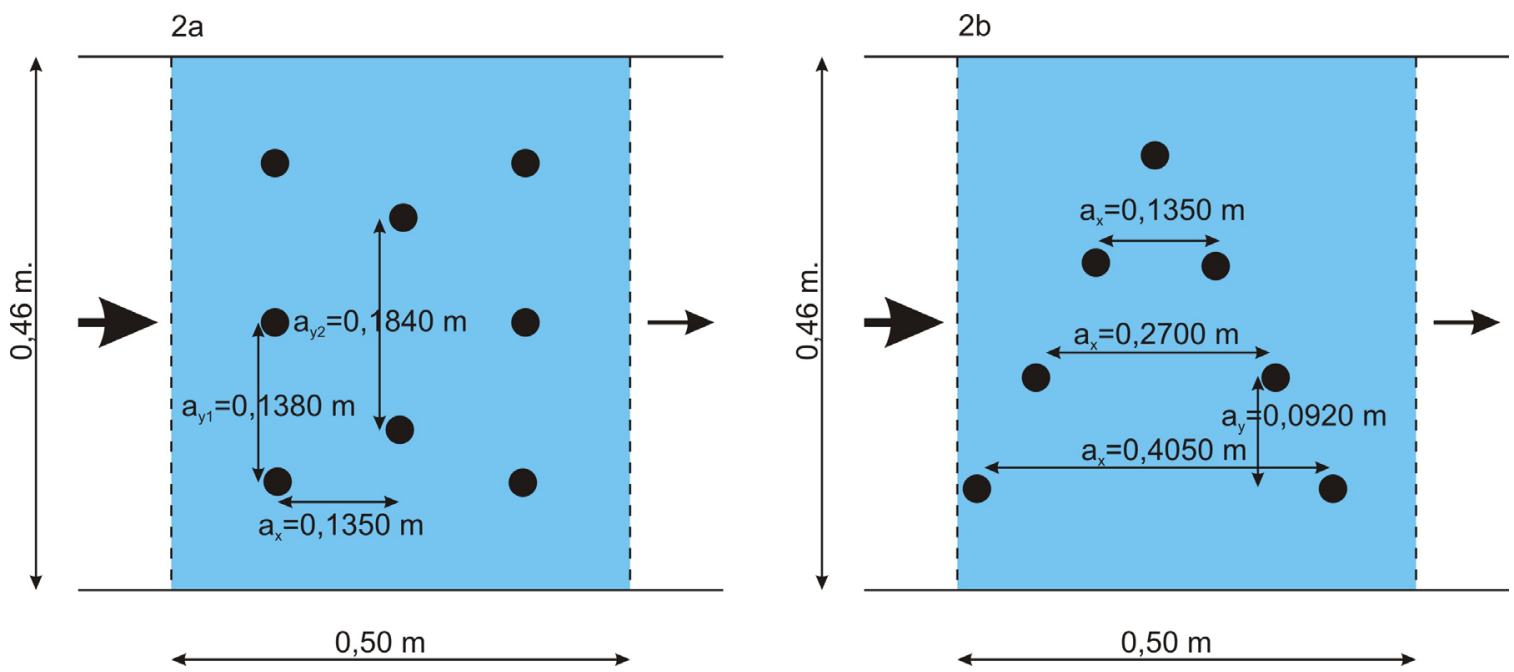

Fig. 3. Diagram of the applied distribution of elements imitating trees in variants $2 a$ and $2 b$ 

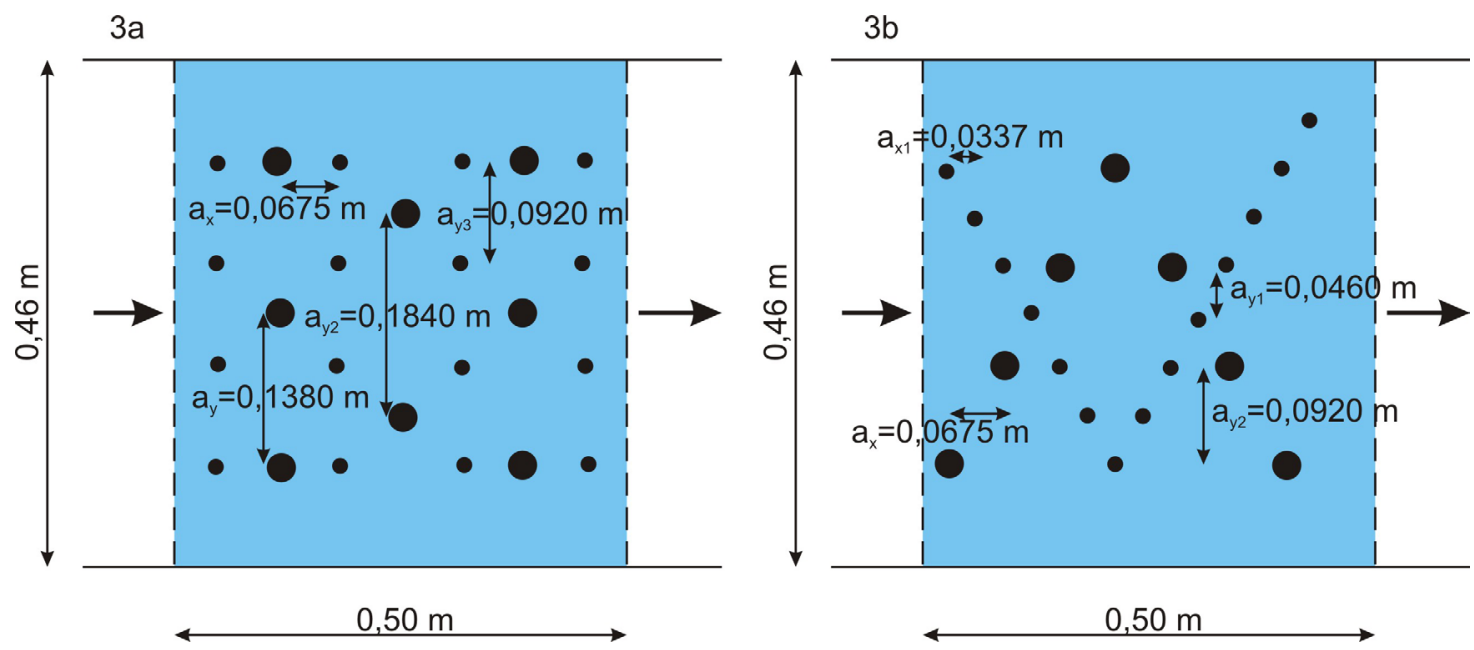

Fig. 4. Diagram of the applied distribution of elements imitating trees in variants $3 \mathrm{a}$ and $3 \mathrm{~b}$

Table 3. Comparison of the probability of passing for debris elements at different levels of shrubby vegetation immersion

\begin{tabular}{|c|c|c|c|c|c|}
\hline Shape debris & $\begin{array}{l}\text { Average plant } \\
\text { spacing Xśr }\end{array}$ & Variant research & Depth H [m] & $\mathrm{Xsr} / \mathrm{H}$ & $\begin{array}{l}\text { Probability of passing } \\
\text { for debris [\%] }\end{array}$ \\
\hline \multirow{9}{*}{$1 \mathrm{~K}$} & \multirow{3}{*}{0.096} & \multirow{3}{*}{$1 a$} & 0.23 & 0.42 & 0 \\
\hline & & & 0.18 & 0.54 & 0 \\
\hline & & & 0.15 & 0.64 & 0 \\
\hline & \multirow{3}{*}{0.113} & \multirow{3}{*}{$1 b$} & 0.23 & 0.49 & 20 \\
\hline & & & 0.18 & 0.63 & 5 \\
\hline & & & 0.15 & 0.75 & 0 \\
\hline & \multirow{3}{*}{0.14} & \multirow{3}{*}{$1 \mathrm{c}$} & 0.23 & 0.60 & 60 \\
\hline & & & 0.18 & 0.77 & 25 \\
\hline & & & 0.15 & 0.92 & 5 \\
\hline \multirow{9}{*}{$1 \mathrm{E}$} & \multirow{3}{*}{0.096} & \multirow{3}{*}{$1 \mathrm{a}$} & 0.23 & 0.42 & 80 \\
\hline & & & 0.18 & 0.54 & 65 \\
\hline & & & 0.15 & 0.64 & 50 \\
\hline & \multirow{3}{*}{0.113} & \multirow{3}{*}{$1 b$} & 0.23 & 0.49 & 85 \\
\hline & & & 0.18 & 0.63 & 65 \\
\hline & & & 0.15 & 0.75 & 40 \\
\hline & \multirow{3}{*}{0.14} & \multirow{3}{*}{$1 \mathrm{c}$} & 0.23 & 0.60 & 90 \\
\hline & & & 0.18 & 0.77 & 75 \\
\hline & & & 0.15 & 0.92 & 45 \\
\hline
\end{tabular}

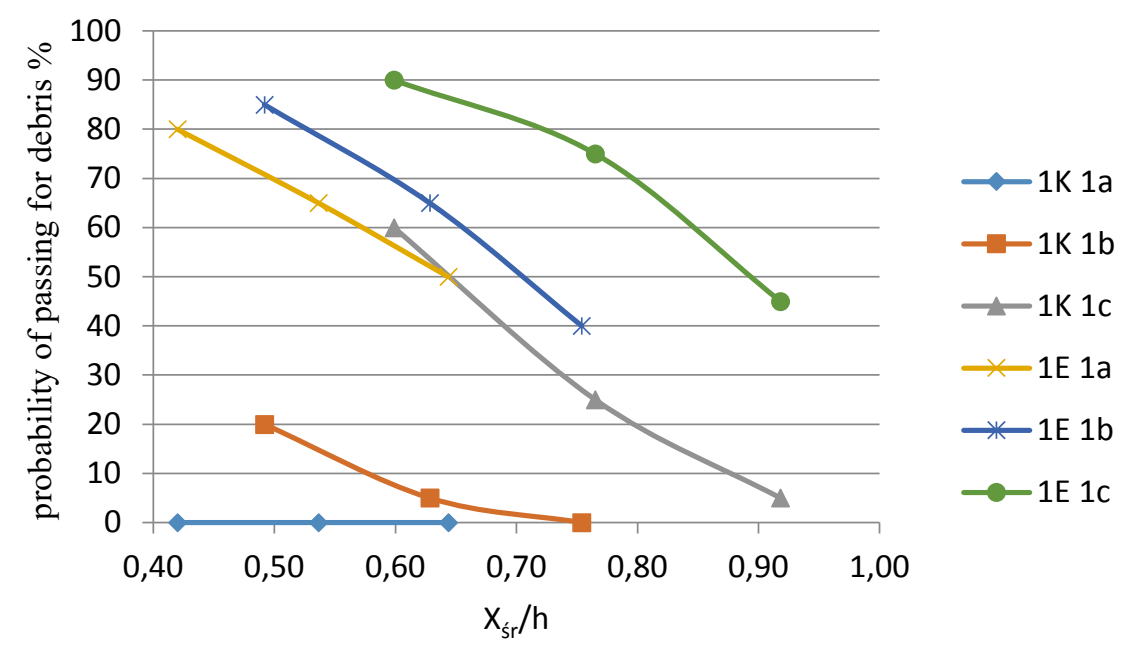

Fig. 5. Probability of passing for elements imitating fine debris through shrubby vegetation 
Table 4. Comparison of the probability of passing for debris elements at different levels of shrubby vegetation immersion

\begin{tabular}{|c|c|c|c|c|c|}
\hline Shape debris & $\begin{array}{l}\text { Average plant } \\
\text { spacing Xśr }\end{array}$ & Variant research & Depth H [m] & $\mathrm{Xsr} / \mathrm{H}$ & $\begin{array}{l}\text { Probability of passing } \\
\text { for debris [\%] }\end{array}$ \\
\hline \multirow{4}{*}{$1 \mathrm{~K}$} & \multirow{2}{*}{0.19} & \multirow{2}{*}{$2 a$} & 0.29 & 0.71 & 25 \\
\hline & & & 0.18 & 1.04 & 15 \\
\hline & \multirow{2}{*}{0.21} & \multirow{2}{*}{$2 b$} & 0.29 & 0.76 & 15 \\
\hline & & & 0.18 & 1.13 & 0 \\
\hline \multirow{4}{*}{$1 \mathrm{E}$} & \multirow{2}{*}{0.19} & \multirow{2}{*}{$2 a$} & 0.29 & 0.71 & 60 \\
\hline & & & 0.18 & 1.04 & 40 \\
\hline & \multirow{2}{*}{0.21} & \multirow{2}{*}{$2 b$} & 0.29 & 0.76 & 65 \\
\hline & & & 0.18 & 1.13 & 15 \\
\hline
\end{tabular}

scribed elements of plant debris. 20 repetitions were performed for each event, for two different filling levels.

Analysing the probability of passing for debris through the area covered with trees only, it can be seen that apart from one case, debris, regardless of its shape, will always pass through. Debris of a square shape is characterized by lesser probability than ellipse-shaped debris.

The probability of passing for ellipse-shaped plant debris through the flood plain covered only with trees is high and in the range from 15 to $65 \%$ (Fig. 6). Square-shaped debris acts differently, with approx. $25 \%$ probability.

The final stage of the study was to conduct the probability evaluation of passing for fine plant debris through the flood plain covered with shrubby and woody vegetation. It used square-shaped (1S) and ellipse-shaped (1E) plant debris elements made of styrodur. The test was conducted for two different filling levels with 20 repetitions. There was analysed the comparison of vegetation with the density of $41 \%$ ( 8 trees and 16 shrubs) as well as $36 \%$ ( 7 trees and 14 shrubs).

Table 5 presents the calculated probability of passing for elements imitating square-shaped fine plant debris $(1 \mathrm{~K})$ and ellipse-shaped fine plant debris (1E) passing between elements imitating shrubby and woody vegetation.

For a dense vegetation structure, irrespectively from the filling level, the probability of passing for vegetation debris in both cases is zero. The tests with the use of mixed structures have shown that even with the density of $36 \%$, there is no possibility of passing or plant debris.

\section{CONCLUSIONS}

There were carried out tests considering the effect of shrubby and woody vegetation on flow conditions for fine plant debris, modelled with the

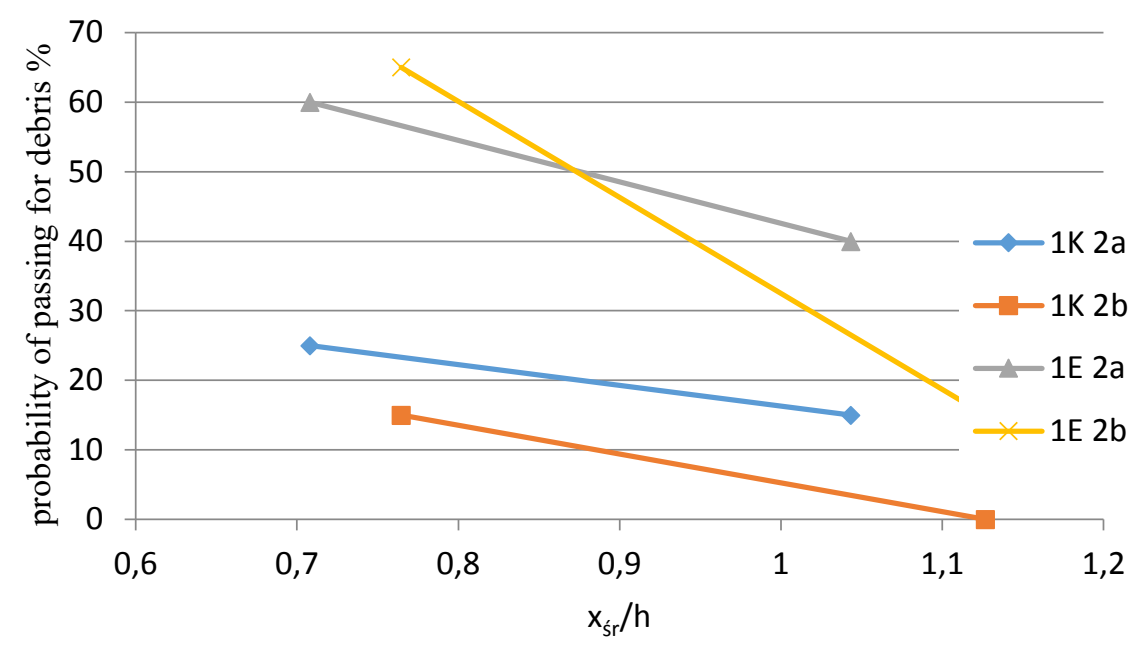

Fig. 6. Probability of passing for elements imitating fine debris through woody vegetation 
Table 5. Comparison of the probability of passing for debris elements at different levels of woody vegetation immersion

\begin{tabular}{|c|c|c|c|c|c|}
\hline Shape debris & $\begin{array}{c}\text { Average plant } \\
\text { spacing Xśr }\end{array}$ & Variant research & Depth H [m] & $\mathrm{Xsr} / \mathrm{H}$ & $\begin{array}{c}\text { Probability of passing } \\
\text { for debris [\%] }\end{array}$ \\
\hline \multirow{4}{*}{$1 \mathrm{~K}$} & \multirow{2}{*}{0.116} & \multirow{2}{*}{$2 a$} & 0.29 & 0.41 & 0 \\
\hline & & & 0.18 & 0.61 & 0 \\
\hline & \multirow{2}{*}{0.124} & \multirow{2}{*}{$2 b$} & 0.29 & 0.44 & 0 \\
\hline & & & 0.18 & 0.65 & 0 \\
\hline \multirow{4}{*}{$1 \mathrm{E}$} & \multirow{2}{*}{0.116} & \multirow{2}{*}{$2 a$} & 0.29 & 0.41 & 0 \\
\hline & & & 0.18 & 0.61 & 0 \\
\hline & \multirow{2}{*}{0.124} & \multirow{2}{*}{$2 b$} & 0.29 & 0.69 & 0 \\
\hline & & & 0.18 & 0.65 & 0 \\
\hline
\end{tabular}

use of flat elements made of styrodur. The experiment was conducted under laboratory conditions applying the imitations of square-shaped and ellipse-shaped plant debris. By modelling different spacing of vegetation occurring in flood plains and different depths of the water table, there was specified the probability of passing for debris in the hydraulic channel.

The study showed that the probability of blocking plant debris on cylindrical elements imitating shrubby and woody vegetation depends on the shape of debris, water flow velocity, and the amount and density of the flood plain vegetation. The probability of debris blockage is higher for square-shaped elements than for ellipse-shaped ones, and it decreases with an increase in the depth of water in the hydraulic channel. As the density of the flood plain is higher (as a result of an increase in vegetation elements), it might be expected that the probability of passing for plant debris is lower. Shrubs in the flood plain area due to their organic material content (leaves, stems, grass elements) "seal" the channel, and the increased density of organic material results in accelerating the process. Furthermore, it can be noted that this type of blockage may lead to excluding the part of a section. Consequently, in case of great water, it may pose a threat to those areas.

\section{REFERENCES}

1. Dąbkowski L.Sz., Pachuta K., 1996. Roślinność i hydraulika koryt zarośniętych. Biblioteczka Wiadomości IMUZ, Wydawnictwo IMUZ, Falenty.

2. Gustowska J., Lubacz E., Kołcun J., 2013. Zabezpieczenie przed powodziami na Dolnym Śląsku. Wiadomości Melioracyjne i Łąkarskie 2, 78-81.

3. Hammerling M., Walczak N., Zawadzki P. Kałuża
T. 2014. Delay in the flow of plant debris on flood plainsover grown with shrub vegetation. Acta Sci. Pol., Formatio Circumiectus 13(4), 95-108.

4. Johnson P.A. and Sheeder S.A. 2011. Debris at Bridges Stream Restoration in Dynamic Fluvial Systems: Scientific Approaches, Analyses, and Tools Geophysical Monograph Series 194, Copyright 2011 by the American Geophysical Union Controlling

5. Kałuża T., Radecki-Pawlik A., 2014. Wpływ grubego i drobnego rumoszu roślinnego na hydrodynamikę koryt rzecznych. Acta Sci. Pol., Formatio Circumiectus 13(1), 67-80.

6. Kubrak J., Kozioł A., Kubrak E., Wasilewicz M., Kiczko A. 2012. Analiza wpływu roślinności na warunki przepływu wody w międzywalu. Określenie kryteriów ustalania miejsc przeprowadzania wycinek i usuwania nadmiaru roślinności. Szkoła Główna Gospodarstwa Wiejskiego w Warszawie. Wydział Budownictwa i Inżynierii Środowiska, Warszawa.

7. Kubrak J., Nachlik E. 2003. Hydrauliczne podstawy obliczania przepustowości koryt rzecznych. Wyd. SGGW, Warszawa.

8. Łoś M. 2013. Ochrona przed powodzią -niektóre wątpliwości, Wiadomości Melioracyjne i Łąkarskie 4, 165-167.

9. Popek Z., Helduk L., Hładki P. 2011. Możliwości wykorzystania przepływomierza modułowego ISCO 2150 w pomiarach hydrometrycznych w małej rzece nizinnej. Przegląd Naukowy Inżynieria i Kształtowanie Środowiska nr 53, 2011Katedra Inżynierii Wodnej SGGW, Warszawa.

10. Radecki-Pawlik A., Wieczorek M., Plesiński K. 2011. Zróżnicowanie parametrów hydrodynamicznych cieku w miejscu zdeponowania grubego rumoszu drzewnego.Acta Sci. Pol., FormatioCircumiectus 10(2), 35-46, Kraków.

11. Walczak N., Przedwojski B. 2005. Wyznaczanie wartości współczynnika oporów terenów zalewowych Warty powyżej zbiornika Jeziorsko. Roczniki Akademii Rolniczej w Poznaniu CCCLXV, Poznań. 